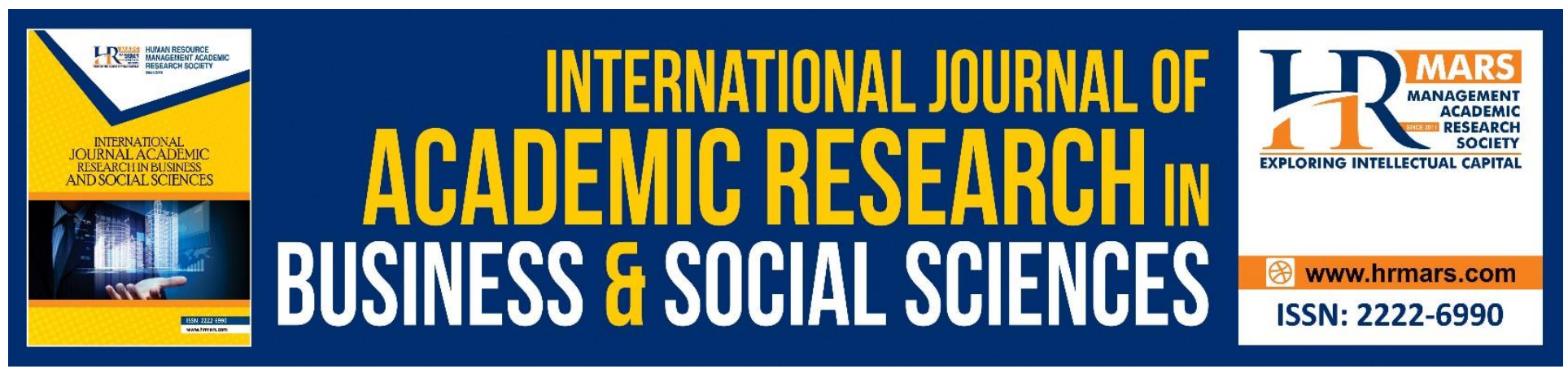

\title{
Assessing the Impact of Corporate Social Responsibilities (CSR) of Multi-National Companies in the Niger Delta Region Nigeria
}

UDEH, Anastasia Ifeoma

ENEJE, Beatrice Chinyere

EZEMA, Kenneth Okwudili

To Link this Article: http://dx.doi.org/10.6007/JJARBSS/v8-i12/5157

DOI: 10.6007/IJARBSS/v8-i12/5157

Received: 12 Nov 2018, Revised: 25 Dec 2018, Accepted: 29 Dec 2018

Published Online: 31 Dec 2018

In-Text Citation: (Udeh, Eneje, \& Ezema, 2018)

To Cite this Article: Udeh, A. I., Eneje, B. C., \& Ezema, K. O. (2018). Assessing The Impact Of Corporate Social Responsibilities (Csr) Of Multi-National Companies In The Niger Delta Region Nigeria. International Journal Of Academic Research In Business And Social Sciences, 8(12), 1104-1120.

Copyright: () 2018 The Author(s)

Published by Human Resource Management Academic Research Society (www.hrmars.com)

This article is published under the Creative Commons Attribution (CC BY 4.0) license. Anyone may reproduce, distribute, translate and create derivative works of this article (for both commercial and non-commercial purposes), subject to full attribution to the original publication and authors. The full terms of this license may be seen

at: http://creativecommons.org/licences/by/4.0/legalcode

Vol. 8, No. 12, 2018, Pg. 1104 - 1120

http://hrmars.com/index.php/pages/detail/IJARBSS

JOURNAL HOMEPAGE

Full Terms \& Conditions of access and use can be found at http://hrmars.com/index.php/pages/detail/publication-ethics 


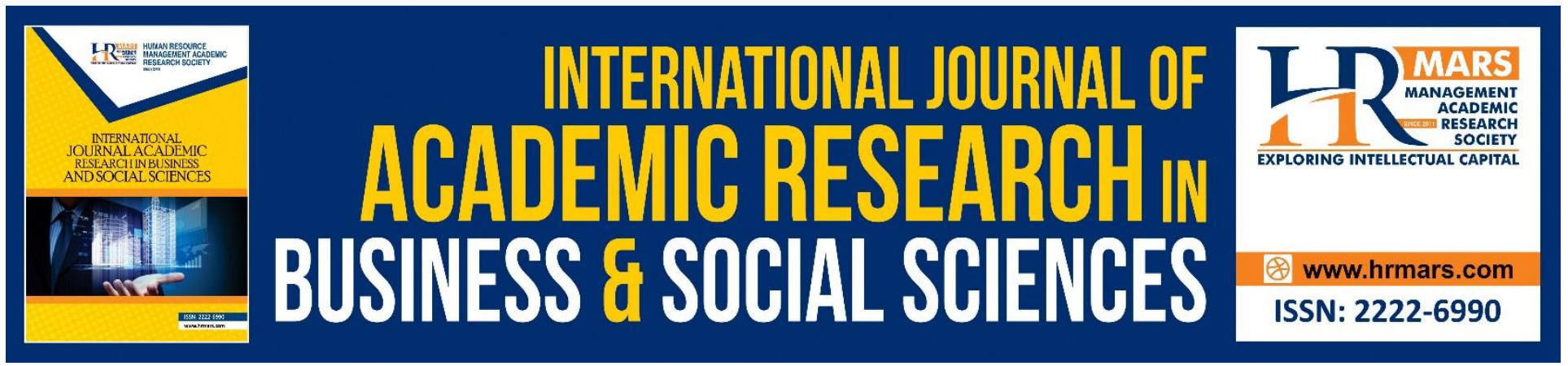

\title{
Assessing the Impact of Corporate Social Responsibilities (CSR) of Multi-National Companies in the Niger Delta Region Nigeria
}

\author{
UDEH, Anastasia Ifeoma \\ Department of Accountancy, School of Financial Study, Institute of Management and Technology, \\ Enugu- Nigeria \\ Email: ifeomau2@yahoo.com \\ ENEJE, Beatrice Chinyere (Ph.D.) \\ Department of Accountancy, Alex Ekwueme Federal University Ndufu Alike, Ikwo Ebonyi State \\ Email: dr.mrseneje@gmail.com

\section{EZEMA, Kenneth Okwudili} \\ Department of Accountancy, School of Financial Study, Institute of Management and Technology,
}

Enugu- Nigeria

\begin{abstract}
This study examines the corporate social responsibilities (CSR) of multi-national companies operating in the Niger Delta Region. Data were obtained from questionnaires administered to 400 respondents drawn from the host communities and the companies. Secondary data were equally used. Data were analyzed using chi-square statistical tools at $5 \%$ level of significance and 2 degrees of freedom. Result revealed that CRS programmes of the multi-national companies are not adequate. The involvement of the host communities in the choice and execution of the programme are not satisfactory to the majority of the host communities. The study recommends that much is still expected from the multinational companies.
\end{abstract}

Keywords: Multinational Companies, Projects, Communities, Niger-Delta 
INTERNATIONAL JOURNAL OF ACADEMIC RESEARCH IN BUSINESS AND SOCIAL SCIENCES

Vol. 8, No. 12, Dec, 2018, E-ISSN: 2222-6990 @ 2018 HRMARS

\section{INTRODUCTION}

The growing spirit of environmental consciousness in organizations has often been expressed in various ways. These include provision of various types of infrastructural facilities and social amenities, support for security, promotion of new initiatives for the host communities, among others (Awuyo, 2005). In this growing phenomenon, environmental management has captured a global emotion. Since the 1992 Rio de Janierio conference, more national and international symposia that have all focused on environmental relevance to institutional growth received added impetus.

And for this, a greater need for corporate commitment to its environment as a surer way to the realization of its primary objective was canvassed and emphasized (Crowder, 2004). There is, therefore, a correlation of current environmental consciousness with that landmark conference of 1992 and other similar ones that followed. As a result, it has become a common belief that large companies have a responsibility to the communities in which they operate which explains why all types of corporate organizations strive hard to meet the expectations of the immediate communities through the provision of social amenities in the spirit of corporate social responsibility philosophy (Davidson, 2006).

In the oil rich region of Niger Delta, the Multinational

companies whose activities dominate every business activity in the area come in sharp focus in this study of environmental responsibility for obvious reasons. Unlike other corporate organizations in the area, these multinational companies have all their operational activities almost intertwined with the environment. They therefore, cannot be extricated from this global environmental campaign (Odukwe, 2006). As participants in the leading sector of the Nigerian economy, the corporate social responsibility role expected from Multinational companies cannot be over-emphasized. Stakeholders expect companies to manage the social and environmental impacts of their operations. In response to these agitations, many Multinational companies have adopted corporate social responsibility (CSR) programmes.

Many of these programmes are not integrated into organization's operations but are merely taken as philanthropic gestures inspite of the grievous consequences in the host communities. Apart from the environmental degradation through oil spillage and gas flaring, there are other issues that have affected the relationship between the Multinational companies and their host communities. Indeed, the relationship between the Multinational companies and some of their host communities in the Niger-Delta, has not been cordial in the recent years owing to different perceptions of the role that the Multinational companies are expected to play in the development process of their host communities. On the other hand, the Multinational companies feel that they are doing enough and have, in fact, gone beyond the realm of normal corporate social responsibility. In the face of conflicting perceptions of the issues in contention, crises have often erupted in the Niger Delta region. What then is the response of the Multinational companies to these crises?

Embodied in virtually all corporate publications of these Multinational oil companies are their claims of commitments to their host communities' environments. In fact, their common slogan is "committed to our communities" (Omeje, 2007). For instance, Shell Petroleum Development Corporation (SPDC), one of the Multinational companies in the region, has often orchestrated advertorials in the national dailies to drum this claimed commitment to community development in the minds of the reading public. In one of such institutional adverts in the Guardian Newspaper of 
$24^{\text {th }}$ October, 2009, the company stated that "our commitment to community development is more than 40 years old. It is natural. These communities are where we work and live. That is why for four decades, we have been partners in development". All other Multinational companies in the areaChevron, Mobil, Elf, Agip etc, equally toe the same line in claiming that the quality and quantity of their community development projects for their host communities which, reflect their commitment, are obviously unequalled (Nnodu, 2010).

However, despite this claimed commitment to the prosecution of these community development programmes, we are often inundated with restiveness occasioned by allegations of insensitivity, lack of commitment/concern and environmental abuse against the multinational companies by the host communities. Consequently, key business outfits are threatened and finally lost on account of hostile reactions from this host community populace (Oladimeji, 2008).

This has been the common pattern of relationship between the Multinational companies in Niger Delta and their host communities in the recent past. While the oil companies claim total commitment to their host communities, these communities return claims of neglect, insensitivity and environmental abuse. This apparent contradiction thus present an unclear picture of reality in the application and implementation of community development project by the Multinational companies to the host communities in the Niger Delta. Either of the parties to the controversy is possibly correct in its claims (Obetta, 2006). The Multinational companies may be fully committed in their social development programmes for the area, but perhaps for the fastidiousness of these host communities who are either probably difficult to satisfy or please or may have truly been neglected by the oil companies. The Multinational companies may just have been employing rhetoric's in their claims of commitment rather than adequate concern, honesty and sincerity (Ideye, 2008). The reality or truth of the matter, therefore, has to be established, hence this study.

This palpable cat and mouse relationship between multinational companies especially Shell and Chevron in the Niger Delta raises a lot of questions. Such questions include: What is the true picture in the Multinational companies' claims of being a committed social leader with the provision of its development projects due to the host communities in terms of hospitals, schools, roads, water, electricity, scholarships etc? How far have the Multinational companies been really committed in the execution of these community development programmes for the host communities in that area, particularly the Port harcourt area? What, in fact, is the level of the multinational companies' commitment and sincerity in their claimed community development programmes in Port-Harcourt? Could they not have been merely playing politics when they claim to have embarked on programmes that remain elusive?

This study is an attempt at examining the corporate social responsibilities of Multinational companies in Nigeria. In doing this, attempt would be made to clarify the concept of corporate social responsibility. Subsequently, an appraisal of the corporate activities of the multinational companies in their host communities would be undertaken with a view to ascertaining their adequacy or otherwise.

\section{STATEMENT OF PROBLEM}

The fundamental aim of business is to survive and grow while its secondary objective is to make the best use of its resources for the betterment of its community. Sadly, these objectives may 
not be achieved by Multinational companies because of some problems associated with their internal and external environments. These include lack of management's commitment to improving the host communities' welfare, unfavourable business condition and environment, inadequate budgetary allocation for CSR programmes, hostile activities' of the host communities, stringent government policies, among others. These factors, playing in concert place limitations on Multinational companies to be adequately and socially responsible in their business communities.

\section{OBJECTIVES OF THIS PAPER}

The objectives of the study are:

1. To examine the CSR projects of the Multinational companies in Port Harcourt

2. To assess the adequacy of CSR programmes of the Multinational companies in their host communities in Port Harcourt.

3. To examine the spread or distribution of these projects in the host communities.

4. To examine the level of participation of the communities in the choice or execution of these projects.

5. To find out how satisfactory the community development projects are for the host communities.

\section{HYPOTHESES}

The above objectives necessitate the following hypotheses:

1. $\mathrm{Ho}_{1}$ : The CSR Projects of the oil firms in Port HarCourt are not essentially physical infrastructures.

2. $\mathrm{Ho}_{2}$ : The CSR programmes of oil firms are not adequate.

3. $\mathrm{Ho}_{3}$ : The spread or distribution of the CSR programmes is not equitable.

4. Ho4: The level of participation of the host communities in the choice or execution of the projects is low.

5. $\mathrm{Ho}_{5}$ : The community development projects are not satisfactory to the host communities.

\section{LITERATURE REVIEW}

\section{Concept and Definition}

Corporate social responsibility (CSR) is a concept which has become dominant in business reporting and it has a myriad of definitions, each of which integrades the three dimensions to the concept - economic( environmental and social dimensions. According to Farel (2007) it is demonstration of certain responsible behaviour on the part of corporate organizations towards society and the environment. A very popular definition of CSR was given by Holmes \& Watts (1990) as the continuing commitment by business to behave ethically and contribute to economic development while improving the quality of life of the work force and their families as well as their local community and society at large. CSR means giving back to the society some of the benefits and gains realized from the society.

Business for Social Responsibility (BSR) a leading Global Business Partner in 2006, defined CSR as achieving commercial success in ways that honours ethical values and respect people, communities and the natural environment. According to BSR, Corporate social responsibility also 
means addressing the legal, ethical, commercial and other expectations society has for businesses, and making decisions that fairly balance all claims of all key stakeholders. In this sense, CSR is viewed as a comprehensive set of programmes, policies, and practices that are integrated into business operations, supply chain and decision-making processes throughout the company and wherever the company does business that are supported and rewarded by top management (Anderson, 2008).

Basu and Palazo (2009) defined CSR as the process by which managers within an organization think about and discuss relationships with stakeholders as well as their roles in relation to the common good, along with their behavioral disposition with respect to the fulfillment and achievement of these roles and relationships. For the European Commission (2001), CSR is a concept whereby companies integrate social and environmental concerns into their business operations and in their interaction with their stakeholders on a voluntary basis. CSR is concerned with treating the stakeholders of the firm ethically or in a socially responsible manner. Since stakeholders exist both within a firm and outside a firm, behaving socially and responsibly will increase the human development of stakeholders both within and outside the corporation (Clarkson, 2005).

According to Steiner (2002) CSR is the intelligent and objective concern for the welfare of the society that retains the individual and corporate behaviour from ultimately destructive activities, no matter how immediately profitable and leads to the directions of positive construction of human betterment. As an improvement on the above definition, (Koontz and O'Donnell, 2004) defined CSR as the personal obligation of everyone, as he acts in his own interests, but he must always have due regard that his freedom does not restrict others from doing the same thing.

In emphasizing the ecological conceptualization of social responsibility, (Egeonu, 2009) noted that any good definition of social responsibility must contain, if not all, most of the following Responsibility that:

i) Goes beyond the production of goods and services at a profit.

ii) Helps in solving important social problems which the organizations are responsible for creating.

iii) Makes organizations have greater constituency than stockholders alone

iv) Makes organizations have great impacts that goes beyond market place transactions, and

v) Makes organizations serve a wider range of human values that can be captured by a sole focus on value.

(Ugbaja, 2008) expressed that there should be a symbiotic relationship between corporate organizations and the host communities as well as an unwritten "social contract", so that it should not be forced responsibility but a voluntary social sucrose based on the needs of the community. Socially responsible business practice implies that CSR is the social practice where the organization adopts and conducts discretionary businesss practice and investments that support social causes to improve community wellbeing in order to protect the environment. Key distinctions include focus on activities that are discretionary and not those that are mandated by laws or regulatory agencies. Indeed, it is about business giving back to society as compensation and appreciation.

According to Nigeria Social Enterprise Reports (2000) CSR is generally understood to be the way an organization achieves a balance or integration of economic, environmental and 
social imperatives while at the same time addressing shareholders and shareholders' expectations. Further, CSR is seen as the contribution of business to sustainable development which is defined as "development that meets the needs of the present without compromising the ability of the future generations to meet their own needs".

In Nigeria, the Federal Executive Council (FEC) in May, 2008 approved the development of a CSR policy for the country, to instill ethical behaviour in Nigerian businesses. (Daggash, 2008), the then Minister of National Planning Commission, said that CSR referred to adoption of responsible business practices by organizations, to improve the society at large. According to him, the policy would include beyond law commitment" and activities that would necessitate an expectation to 'give back' to the society. It would also ensure corporate governance and ethics, health and safety, human rights, human resource management, etc. The key CSR issues addressed in the policy included Human Rights, Employee Rights, Environmental Protection, Community Involvement and Supplier Relations.

\section{CHARACTERISTICS OF CORPORATE SOCIAL RESPONSIBILITIES}

The European foundation for Quality Management (EFQM) presents some common characteristics for CSR which are;

i) Meeting the need of current stakeholders without compromising the ability of future generations to meet their own demand.

ii) Adopting CSR voluntarily, rather than as legal requirement, because it is seen to be in the long-term interests of the organization.

iii) Integrating social, environmental and economic policies in day to day business, and

iv) Accepting CSR as a core activity that is embedded into an organization's management strategy.

\section{Responsibilities of the Firm}

To achieve set objectives according to (Omeje, 2007) every corporate business owes various duties to all the stakeholders. These according to (Oke, 2007) include;

i) Duty to protect the well-being of people in its environment. A companies primary duty is to protect the well-being of those living within its area or environment of operation.

ii) Duty to produce goods and services that are not harmful to the people such goods should not cause death to people.

iii) Duty not to deceive others. Deception, as implied here, include failing to include all the acquired quantities and quality materials for producing a particular product, colluding with the external auditor to render false financial statements to shareholders, regulatory authorities and members of the public, etc.

iv) Duty not to engage in fair binding contracts with its customers, creditors, employees, suppliers, etc. All terms and conditions of the contracts should be well-staged by the firm and well understood by the parties concerned.

v) Duty to make reasonable return to shareholders in accordance with the level of investment. 
vi) Duty to minimize harmful effect of substance. In the course of doing business, firms are bound to engage in activities whose effects may be harmful or distasteful to members of the organization and the public.

vii) Duty to pay reasonable salaries and wages to the employees. It is the duty of the firm to use the revenue generated from its business activities to pay fair and reasonable compensation in the form of salaries and allowances to workers.

viii) Duty to use part of the firm's profit to provide amenities that promote, the common good of the community in which it operates.

ix) Duty to embark on projects that brings about the expansion and improvement in the company's operations, and

x) Duty to honour obligations to the governments in terms of payments of taxes and levies, thereby making funds available to the government to provide infrastructure facilities and meet the recurrent expenditures with a view to promoting national development.

\section{Corporate Social Activities of Multinational companies in the Niger-Delta Region; Shell Petroleum Development Corporation (Nig.) Ltd and Chevron Ltd.}

Shell Petroleum Development Corporation (SPDC) and Chevron are two of the leading oil companies operating in the Niger-Delta region. It was observed that in the emporia of the discovery of oil in commercial quantity in the Niger Delta, the oil firms cared little by way of CSR to their host communities in the period 1958-1968 (Ibitimi, 1995). But with the evolving wave of communal unrest arising from agitation for compensation, the Multinational companies initiated pragmatic corporate response to the emerging threat to oil business. (Ibitimi, 1995) remarked that the oil companies have lofty CSR objectives:

Shell, in her statement of "General Principle" recognizes society as one of the first groups to which Shell Company owes a responsibility. Others are shareholders, customers, employees and those with whom they do business. Chevron's statement on "mission and vision" states among other things, that it will establish an enduring and mutually beneficial relationship with the people. These lofty general statements are note worthy on their face value. But the reality on the ground seems to believe these claims. In the realm of payment of compensations, the Multinational companies insisted that they have adequately discharged their responsibilities to their host communities. (Ewere, 2005) expressed that the multinational companies were disposed to CSR in their host communities.

The two oil companies appear to have much to show in their CSR $\mathrm{n}$ the Niger Delta in the area of provision of infrastructures as community development projects. These projects, according to Ewere (2005) include provision and maintenance of basic amenities for host communities such as portable water, roads and market stalls, other projects relate to education, health, sports and construction as well as skills acquisition schemes. The oil companies concentrated more on improving education and health status of the communities by building, equipping and staffing health centres.

According to (Ighodaro, 2006) in 1986, Shell presented a standard operating table to the Baptist Hospital Eku. A number of government hospitals were refurbished across the region, notably at Sapele, Ozoro and Agbarho. Chevron executed similar projects at Warri, Obiaruku and Escravos 
INTERNATIONAL JOURNAL OF ACADEMIC RESEARCH IN BUSINESS AND SOCIAL SCIENCES Vol. 8, No. 12, Dec, 2018, E-ISSN: 2222-6990 @ 2018 HRMARS

areas of Delta State. Agip and Mobil carried out such projects concentrating in Cross Rivers and AkwaIbom States. Shell and ELF concentrated their own projects in Rivers and Bayelsa states respectively. Also, Shell and ELF registered much presence in Edo State.

However, (Ighodaro , 2006) expressed that despite the apparent absence of social infrastructures in most parts of the Niger Delta region, oil companies are priding themselves of having provided so much for the oil producing communities. Reports have it that when clinics are built, the oil companies call them health centres and when dispensaries are built they call them hospitals. What is worst is that most of these amenities provided are appallingly inadequate. Besides, they functioned for only a few months after the nose of the initial commissioning. For example, the Utu-Jeremy Clinics commissioned by Shell in 1997 lacked basic facilities for its effective functioning until it was improved in 2007.

The Multinational companies also try to deal with the unemployment problem in the region through skills acquisition programmes. They attempt to encourage local skills in the Niger Delta. They make efforts to develop and modernize occupations that are indigenous to the host communities. One of the major crops of the region is cassava. To this end, between 1988 and 2008, oil companies spent millions of naira on the establishment of modern cassava farms. Some of these farms are located in Akieowo, Urwaianuse, Igbanke, Uromi, Sapele and Obiaruku. (Ofili and Atao, 2010). These farms employ modern and scientific methods in processing cassava into garri, courtesy of Shell, and Chevron.

A supplement to this is the provision of cassava cuttings, pineapple suckers and oil palm seedlings to farmers at subsidized rate. The Aghardo farming centre, comprising Seed Multiplication and research Centre has been making improved variety of cassava cutting available to farmers. Periodic training is held with farmers by extension officers (workers who educate and advise farmers on new agricultural techniques.

The Multinational companies also engage in the employment of idle hands through skills acquisition. The SPDC initiated the Youth Development Scheme (YDS) which she conceived as a means of channeling the energy of youths in oil producing communities to engage in gainful economic activities through the acquisition of entrepreneurial usable and marketable skills that would make them relevant to themselves (Ofili and Alao, 2010). The trainees are attached to master trainers who are paid by shell. Chevron, Mobil and ELF also established similar programmes in their host communities in Cross River, Akwa-lbom, Rivers, Bayelsa, Edo and Delta States.

Ola et al (2011) some of the criteria that are used in selecting communities that have benefited from these schemes are;

$$
\begin{aligned}
& \text { - } \quad \text { Oil producing community }-40 \% \\
& \text { - } \quad \text { Population - } 5 \% \\
& \text { Proximity to oil company facilities and number/nature of the facilities }-10 \%
\end{aligned}
$$

Based on the above criteria, quota was allocated to each participating community. The communities were then given the responsibility to select their candidates. As at 2010, not less than 1,620 people had benefited from these schemes in selected areas in all the Niger Delta States (Olariwaju, 2012). Shell and Chevron also claimed that more than 3,900 of their staff or $57 \%$ of their workforces are from the oil producing states. 
The Multinational companies have always advanced the argument that youths in the Niger Delta do not possess the requisite educational qualifications, hence they have slim chance for employment in the oil industry. (Olariwaju, 2012) explained that this is the reason for the educational support of Multinational companies to their host communities. Shell and Chevron claim to have been providing education support to people in their host communities. Since the past three decades, between 1995 and 2010, Shell provided 3,647 scholarships to University students in all it areas of operations in the Niger Delta region and Chevron provided same to about 3,122 university students (Bidieke, 2011). The figure for post primary school scholarship is more commendable as about 24,026 students have benefited from Shell and Chevron in the same period.

The Multinational companies appear to be gender sensitive in their corporate responsibilities. This is manifested in the elaborate attention given to women issues in the Niger Delta. This is attributed to the significant role of women in the local economy of the region. Women are considered to be the worst victims of the negative externalities from the multinational companies operations. It is in realization of this that shell established a women's programme to promote active involvement of women in the sustainable development of the oil rich communities. Shell established the Rumuokwarasi project in partnership with women who trade in fresh fish. The shell women vocational training centres at Yenegoa, Port Harcourt and Efurun provide training for women focusing on soap and pomade making. Chevron did same in Ikom, Warri, Sapele and Okirika (Ofili and Alao, 2010). The assistance to fresh fish sellers is significant. It looks like a tacit acceptance of the fact that there is truly a dearth of fish in the region due to oil pollution and other forms of environmental degradation as a result of oil production. The establishment of skills acquisition centres for women in the area may go a long way in reducing the high scale of prostitution in the area.

\section{Methodology}

The data used in this study were collected from Primary and Secondary sources. The Primary data were collected mainly with questionnaires distributed to a sample of 200 respondents of the oil companies as well as 200 locals in the Niger Delta region. The questionnaires were designed to examine the CSR Programmes, assess their adequacy, examine their spread/distribution, level of participation of the Communities in the choice and execution as well as determine the extent to which they are satisfactory, Secondary data were gathered from Secondary sources such as books, journals and other publication.

The Chi-square $\left(\mathrm{x}^{2}\right)$ technique was used to test the hypotheses in order to achieve the objectives of this paper. The hypotheses were tested at $5 \%$ significance level and 2 degrees of freedom which established the critical value of $x^{2}$ as 5.991. 
INTERNATIONAL JOURNAL OF ACADEMIC RESEARCH IN BUSINESS AND SOCIAL SCIENCES

Vol. 8, No. 12, Dec, 2018, E-ISSN: 2222-6990 C 2018 HRMARS

\section{TEST OF HYPOTHESES AND INTERPRETATION OF}

\section{RESULTS}

In this section, the five hypotheses stated earlier were tested using chi-square $\left(x^{2}\right)$ test of statistical significance. The procedure is follows;

$$
\begin{aligned}
& x^{2}=\left\{\frac{\left(O_{i}-O_{e}\right)^{2}}{O_{i}}\right. \\
& \text { Where } \mathrm{Oi}=\text { Observed frequency } \\
& \mathrm{O}_{\mathrm{e}} \quad=\quad \text { Expected frequency }
\end{aligned}
$$

The computed $X^{2}$ value would then be compared with its critical value at $5 \%$ significance levels and 2 degrees of freedom which is 5.991 .

\section{Decision Criteria:-}

We accept $\mathrm{H}_{0}$ and reject $\mathrm{H}_{1}$ of the computed $\mathrm{X}^{2}$ value is less than its critical value.

\section{Test of Hypothesis I}

$\mathrm{Hol}$; The CSR projects of the oil companies in PH are not essentially physical infrastructures.

$$
\begin{aligned}
X^{2} & =\frac{(209-400)^{2}}{400} \\
& =\frac{191}{400} \\
& \frac{36481}{400}
\end{aligned}
$$

Presentation of Result

$\mathrm{X}^{2}=91.2$

\section{Interpretation of Result 1}

The computed $X 2=91.2$ which is greater than 5.99. Based on the decision criteria, we reject $\mathrm{H}_{\mathrm{O}}$ and accept the alternative. This means that the CSR projects of the oil companies are essentially physical infrastructures.

Test of Hypothesis 2

$\mathrm{HO}_{2}$; The CSR programmes of oil firms are not adequate.

$$
x 2=\frac{(35-400)^{2}}{400}
$$




$$
\begin{aligned}
& =\frac{(46)^{2}}{400} \\
& =\frac{2116}{400} \\
& =5.29
\end{aligned}
$$

\section{Interpretation of Result}

The computed X2 is 5.29 which is less than its critical value (5.991). Based on the decision criteria, we accept $\mathrm{H}_{\mathrm{o}}$ and reject the alternative. This implies that the CSR programmes are inadequate.

\section{Test of Hypothesis 3}

$\mathrm{Ho}_{3}$; The spread or distribution of the CSR projects is not equitable

$$
\begin{aligned}
X^{2} & =\left\{\frac{(361-400}{400}\right)^{2} \\
& =\frac{39^{2}}{400} \\
& =\frac{1521}{400} \\
& =3.8
\end{aligned}
$$

\section{Presentation of Result}

$$
\mathrm{X}^{2}=3.8
$$

\section{Interpretation of Result}

The computed $X^{2}$ (3.8) is less than its critical value (5.99). This we accept $\mathrm{H}_{\mathrm{o}}$ and reject the alternative. This means that the spread or distribution of the projects is not equitable.

\section{Test of Hypothesis 4}

$\mathrm{Ho}_{4}$; The level of participation of the host communities in the choice or execution of the projects is low.

$$
\begin{aligned}
X 2 & =\{(\underline{372-400}) 2 \\
400 & \\
& =(\underline{26})^{2}
\end{aligned}
$$




400
$=\quad \frac{676}{400}$
$=\quad 1.69$

\section{Presentation of Result}

$X^{2}=1.69$

\section{Interpretation of Result}

The computed X2 is 1.69 which is less than its critical value (5.991). This implies that the level of participation of the locals in choosing or executing the projects is low.

\section{Test of Hypothesis 5}

Ho5: The community development projects are not satisfactory to the lost communities.

$\begin{aligned} X 2 & =\left\{\frac{(359-400}{400}\right)^{2} \\ & =\frac{41^{2}}{400} \\ & =\frac{1681}{400} \\ & =4.2\end{aligned}$

Presentation of Result

$$
\mathrm{X}^{2}=4.2
$$

\section{Interpretation of Result.}

The computed $X^{2}(4.2)$ is less than critical value (5.99). We than accept Ho and conclude that the community development projects are not satisfactory to the host communities.

\section{FINDINGS AND DISCUSSION}

The result of the first hypothesis which states that the CSR projects of the oil firms are not essentially physical infrastructures shows that the computed X2 value is 91.2 which is more than its critical value (5.991). This means that the projects consist more of infrastructural facilities such as roads schools, hospitals, etc. 
The result of the second hypothesis shows that the computed value of $X 2$ is 5.29 which is less than the critical value of (5.99). As a result it is accepted that the CSR programmes of the oil companies in host communities is not adequate. This finding correlates with the allegations by many observers and environmentalists in the Niger Delta who are of the view that the oil companies are not doing much by way of fulfilling their corporate social responsibilities. For many, the number of social development projects in the region by oil companies is small relative to what they exploit the communities therein. Ugbaja and Ozuh (2008) in their report on CSR activities of oil companies in the region remarked that the companies claimed making expenditures on CSR activities. In spite of the huge expenditures feelings of discontentment is always expressed by the people in the form of violence and crises in the region.

The result of hypothesis three which stated that the spread or distribution of the CSR Projects is not equitable indicated that the computed $X 2$ value is 3.8 which is below 5.99. Thus, the null hypothesis is accepted. This implies that the spread or distribution of the projects is equitable. While the Multinational companies claim that their CSR programmes are evenly spread through urban and rural areas in the Niger Delta, critics posit that they are not. Some claim that they are not evenly distributed among the component states. While some states are favoured more, others are less favoured with citing of the projects. Others allege neglect of urban centres which are fast turning into slums.

For the fourth hypothesis, which states that the level of participation of the host communities in the choice or execution of the projects is low and the computed $X^{2}$ value is 1.96 against 5.99 critical value. The null hypothesis is accepted indicating that the level of participation of the people in the choice and execution of the CSR projects is low. Most of the CSR projects planning and execution are management decisions in the Multinational companies. The leaders of the communities do not make significant contributions. These leaders make minimal contribution at the planning and execution levels.

Finally, with a computed $X^{2}$ value of 4.2 and critical value of 5.99 , the fifth null hypothesis which states that the CSR projects are not satisfactory to the host community is accepted. This means that the communities are not satisfied with the CSR projects. Studies have shown that these projects are not satisfactory to all the people in the communities. The projects are supposed to help improve the life of the people but most of them have been found to be ineffectively functioning. Most of the people are not satisfied with their quality. What could be considered qualitative to some extent is road construction and rehabilitation. Past studies found that the multinational companies have done remarkably well in the construction of access and other road network in the Niger Delta. Achibong et al (2009) remarked that the roads constructed by the oil companies serve their own interest more than the rural communities as their heavy duty trucks normally traverse these roads.

These roads by-passed villages and do not serve as thorough fares to the villagers as they are private roads with intimidating signs. Thus, the effectiveness of these projects is limited in a number of ways as the CSR projects have failed to satisfy the desire of the majority of the people. 
INTERNATIONAL JOURNAL OF ACADEMIC RESEARCH IN BUSINESS AND SOCIAL SCIENCES

Vol. 8, No. 12, Dec, 2018, E-ISSN: 2222-6990 C 2018 HRMARS

\section{CONCLUSION}

The Multinational companies in the Niger Delta claim to have vibrant policy on corporate social responsibility. This they demonstrated in the provision of infrastructures, scholarships, agricultural assistance, employment and economic empowerment of the people through various schemes. The Multinational companies have always applauded themselves that they have done enough. This paper has tried to ascertain the extent to which this is true.

There is evidence that the Multinational companies have provided many social infrastructures, agricultural ventures and other development schemes. But there are divergent views on the spread or distribution of these projects in the region, such as the level of participation of the host communities in the choice and execution of the CSR projects. In conclusion, to the extent that these projects are unsatisfactory to a majority of the people, the Multinational companies still have much to do by way of improving the CSR projects.

\section{REFERENCES}

Achibong, C. and Utoro, O (2009) "CSR Programmes of Oil Companies; A Survey of Selected Communities in the Niger Delta".A Journal of International Studies. Vol 3 (2); 112-118

Anderson, F. (2008) Corporate Social responsibility; Concept Policy and Practice. London: Botten Publishers.

Awuyo, K. (2005) Business and Social Responsibility Ibadan: Spectrum Press.

Basu, S., and Palaso, V. (2009) "The Case for CSR in Mining Regions" Journal of Business Studies. Vol. 15(3);89-96.

Bidieke, F. (2011) "Oil Companies and Human Empowerment in the Niger Delta area" The Nation. Thursday, September 10.

Clarkson, D. (2005) Business and Environmental Management. New York: McGraw-Hill Inc.

Crowder, T. (2004) Corporate Management and Environmental Responsibility. New York: PrenticeHall Inc.

Daggash, S. (2008) “Nigeria's Policy on Corporate Social Responsibility” The Guardian. Friday May 30

Davidson, P. (2006) Environmental Public Relations Management. London: Botten Press

Egeonu, P. (2004)" Managing the Environmental Pollution in the Niger Delta; The case for CSR" Policy Paper

European Commission (2001)" Corporate Social Responsibility in Europe" Social and Economic Development Journal. Vol. 27 (6); 220 -228 
INTERNATIONAL JOURNAL OF ACADEMIC RESEARCH IN BUSINESS AND SOCIAL SCIENCES

Vol. 8, No. 12, Dec, 2018, E-ISSN: 2222-6990 C 2018 HRMARS

Ewere, M. (2005)"Oil Companies and Environmental Management In Delta State" Journal of Business Management. Vol. 30(8); 302-318

Farel, V. (2007) Corporate Management. London cassel Ltd.

Holme, F. and Watts, K. (1990)" Corporate Social Responsibility: Concept and Practice In England" Journal of Business Research. Vol. 49 (6); 183-190

Ibitimi, K. (1995)" Oil Companies and Development Programmes in Nigeria" Management In Nigeria. Vol. 10(8); 68-80

Ideye, B. (2008)" CSR of Oil Companies In Nigeria" The Sun. Wed. Feb. 20

Ighodaro, E. (2005)" A Survey on CSR projects of Oil firms in the Niger Delta" Management in Nigeria. Vol. $18(2) ; 112-119$

Koontr, D. and O’ Donnel, C. (2004) Management, New Jersey: Prentice -Hall Inc.

Nnodu, K. (2010)" CSR and Niger Delta Development" The Nation. Thurs April 10

Obetta, C. (2006)" CSR of shell and Cherron in the Niger Delta" Journal of Management. Vol. 2(4); 101-108

Odukwe, C. (2006)" CSR Projects in the Niger Delta by Oil firms ; How far? The Guardian. The. July 26

Ofili; C and Alao, J(2010)" CSR and Community Development; A

Survey of selected communities in the Niger Delta" Journal of Business Studies. Vol. 18(10); 123-131

Oke, D. (2007) Corporate Social Responsibility. Lagos: Intec

Ola, A. and Okeke, O. (2011)" CSR programmes of Oil firms in the Niger Delta" Oil Magazine. Vol. 41 (6); 82-93

Oladimeji, A. (2006)" Oil firms in CSR in the Niger Delta States" Oil Magazine. Vol. 36 (2);191-202

Olarioaju, P. (2012)" CSR programmes and Community Development in South -South States" The Manager, June 28

Omeje, P.(2007) Corporate Management in Nigeria. Enugu: JTC Publishers

Steiner, V. (2002) Business And Environmental Management. New York; Harper \& Row Inc 
INTERNATIONAL JOURNAL OF ACADEMIC RESEARCH IN BUSINESS AND SOCIAL SCIENCES

Vol. 8, No. 12, Dec, 2018, E-ISSN: 2222-6990 @ 2018 HRMARS

Ugbaja, C.O. (2009)" A Survey on CSR Programmes of Oil Firms In Edo State" MBA Dissertation

Ugbaja, C.O. and Ozuh, E. (2008)"CSR and Community Development in Niger Delta" Management Journal Vol. 12(3); 45-58 